Short Note

\title{
Inclusion of Red seaweed (Hypnea musciformis) improves nutritional quality of vegetable salad
}

\author{
MD. ENAMUL HOQ ${ }^{* 1}$, MOHAMMAD ASRAFUL HAQUE, \\ JAKIA HASAN, MD. ZAHIDUL ISLAM ${ }^{2}$ and MD. MOHIDUL ISLAM \\ Marine Fisheries \& Technology Station, BFRI, Cox's Bazar 4700, Bangladesh \\ ${ }^{1}$ Present address: Bangladesh Fisheries Research Institute (BFRI), Mymensingh 2201, Bangladesh \\ ${ }^{2}$ Present address: Dept. of Chemistry, Govt. Suhrawardi College, Pirojpur \\ *Email: hoq_me@yahoo.com
}

\begin{abstract}
Nutritional properties of vegetable salad incorporated with red seaweed (Hypnea musciformis) was evaluated. Two lots of vegetable salad were prepared viz., control salad without adding seaweed and seaweed salad with inclusion of $20 \%$ seaweed along with cucumber, tomato, carrot, cloves, garlic, lemon and salt. Micronutrient composition indicated that addition of seaweed increased the $\mathrm{Ca}, \mathrm{Na}, \mathrm{Fe}$ and $\mathrm{Zn}$ content of vegetable salad. Calcium and iron content was substantially higher in seaweed mixed salad. The results indicate that incorporation of seaweed in vegetable salad improves the nutritional content and hence can be used to enrich nutritional quality of food salad.
\end{abstract}

Seaweeds are classified taxonomically as algae and they represent as seafood in coastal countries. In many Asian countries, seaweeds are consumed raw, with salads or with cooked vegetables. Seaweeds are rich in essential nutrients, especially trace elements and bioactive compounds. Seaweeds contain carbohydrates different from those in higher land plants and in addition, high protein content (Arasaki and Arasaki 1983). Typical nutritional analyses of seaweeds have identified high levels of carbohydrates as well as minerals, vitamins, and trace elements such as iodine (Morrissey et al. 2001). People of Bangladesh are not yet familiar with using seaweeds as food supplements. Only ethnic community use seaweeds in their daily diets. In Bangladesh, the natural abundance of seaweeds are reported from the south-eastern part of the mainland, offshore island- St. Martin's Island, Cox's Bazar and Kuakata beach, Patuakhali. Korean people consume seaweeds on an average $8.5 \mathrm{~g} /$ adult/day, whereas Chinese people consume $5.2 \mathrm{~g}$ and Japanese people consume $4 \mathrm{~g} /$ adult/day (Hwang et al. 2010). The present study evaluated the nutritional quality of red seaweed (Hypnea musciformis) incorporated vegetable salad against the traditional one.

Most commonly available edible red seaweed, Hypnea musciformis was collected from Saint Martin's Island, Cox's Bazar by hand picking, washed several times and used in salad. In a trial, normal salad was prepared with cucumber, tomato, carrot, cloves, garlic, lemon and salt. Seaweed salad was prepared with 2 cups of thinly sliced clean seaweed (H. musciformis), 3 small cloves, 4 garlic ( 2 smashed, 2 thinly chopped), juice of 1 lemon, $100 \mathrm{~g}$ carrots, $200 \mathrm{~g}$ tomato, $100 \mathrm{~g}$ cucumber and salt as required. The seaweed, smashed garlic, half of the lemon juice, 5 cups water and salt were taken in a large saucepan. The saucepan was covered and brought to a boil and then the carrot was added and cooked for 2 min. Half of cucumber and tomato slice, mint and the boiled seaweed were mixed in a large bowl. The remaining half of 
tomato was blended with the reserved poaching liquid and then the remaining lemon juice, chopped garlic and salt were added.

The vegetable salad samples (both with and without seaweed) were analyzed for their micronutrient contents. Samples were subjected to acid digestion and analyzed according to the procedure described by Farias et al. (2002). Mineral analysis was carried out using inductively coupled plasma atomic emission spectroscopy (ICP-AES, Perkin- Elmer, and Optima 2000). All determinations were performed in triplicate and data were represented on dry weight basis as mean values (Mean \pm standard deviation). The micronutrient content of vegetable salad with and without seaweed are presented in Table I.

Table I. Micronutrients enrichment of salad with seaweed

\begin{tabular}{lccccc}
\hline $\begin{array}{l}\text { Food items/ } \\
\text { Minerals }(\mathrm{mg} / 100 \mathrm{~g})\end{array}$ & $\mathrm{Ca}$ & $\mathrm{K}$ & $\mathrm{Na}$ & $\mathrm{Fe}$ & $\mathrm{Zn}$ \\
\hline Normal vegetable salad & $833.05 \pm 0.2$ & $6,507.82 \pm 0.2$ & $15,636.07 \pm 0.5$ & $16.29 \pm 0.5$ & $4.93 \pm 0.1$ \\
Salad with seaweed & $1,565.14 \pm 1.0$ & $6,031.64 \pm 0.8$ & $17,663.24 \pm 0.1$ & $154.17 \pm 0.6$ & $8.85 \pm 0.2$ \\
\hline
\end{tabular}

The micronutrients i.e. calcium, sodium, iron and zinc level were high in salad with seaweed, however, potassium level was little bit decreased in seaweed mixed salad (Table I). Minerals, such as calcium, accumulate in seaweeds at much higher levels than in terrestrial plants (Institute of Phytonutrition 2004, McCance et al. 1993). Calcium and zinc levels were found to be double after inclusion of seaweed in salad. Sodium and potassium are also present in seaweeds at relatively high levels, although $\mathrm{Na}: \mathrm{K}$ ratios are usually below 1:5 (Ruperez 2002). Minerals are very important for the biochemical reaction in the human body as a cofactor of enzyme. For examples, $\mathrm{Ca}, \mathrm{P}$, and $\mathrm{Mg}$ build and maintain bones and teeth, whereas, $\mathrm{Na}$ and $\mathrm{K}$ help maintain balance of water, acids and bases in fluids outside of cells, and transfer of nutrients in and out of individual cells (Ensninger et al. 1995). Inclusion of red seaweed in vegetable salad resulted increased level of iron in food. In Asia seaweeds have been used for centuries in salads, soups and as low calorie dietetic foods. The dietary fibre which constitutes 25-7\% of the dry weight of marine algae and represents their major component, is primarily souble fibre (Jiménez-Escrig and Sánchez-Muniz 2000). Moreover, adding of seaweeds or their extracts to food products will help in reducing the utilization of chemical preservatives (Gupta and Abu-Ghannam 2011). In Bangladesh, seaweeds have been traditionally utilized as human food by the tribal people. In recent years, few restaurants are often used seaweeds as fresh salads, cooked vegetables and curry dishes. The efforts in seaweed cultivation and its utilization through product and process development could help meet the food and nutritional security of Bangladeshi population as well as augmenting value of total fisheries export. The results obtained in the present study would help motivate people to include seaweed in the daily meals, particularly in salad.

\section{Literature Cited}

Arasaki, S. and T. Arasaki, 1983. Vegetables from the sea. Japan Publication International, Tokyo. $196 \mathrm{p}$. 
Ensminger, A.H., M.E. Ensminger, J.E. Konlande and J.R.K. Robson, 1995. The Concise Encyclopedia of Foods and Nutrition. CRC Press, Boca Raton. Florida, USA.

Farias, S., S.P. Arisnabarreta, C. Vodopivez and P. Smichowsi, 2002. Levels of essential and potentially toxic trace metals in Antarctic macro algae. Spectrochimica Acta Part B, 57: 2133-2140.

Gupta, S. and N. Abu-ghannam, 2011. Recent developments in the application of seaweeds or seaweed extracts as a means for enhancing the safety and quality attributes of foods. Innov. Food Sci. Emerg. Technol., 12: 600-609.

Hwang, Y., S. Park, G. Park, S. Choi and M. Kim, 2010. Total arsenic, mercury, lead, and cadmium contents in edible dried seaweed in Korea. Food Add. Contamin. Part B, 3: 7 13.

Institut de Phytonutrition, 2004. Functional, health and therapeutic effects of algae and seaweed. Institut de Phytonutrition electronic database. Version 1.5. Beausoleil, France.

Jiménez-escrig, A. and F.J. Sánchez-muniz, 2000. Dietary fibre from edible Seaweeds: Chemical structure, physicochemical properties and effects on cholesterol metabolism, Nutrition Res., 20: 585-598.

McCance, R.A., E.M. Widdowson, B. Holland, 1993. McCance and Widdowson's Composition of Foods. 6th ed. Cambridge, Royal Society of Chemistry.

Morrissey, J., S. Kraan and M.D. Guiry, 2001. A Guide to Commercially Important Seaweeds on the Irish Coast. Dublin, Bord Iascaigh Mhara/Irish Fisheries Board. 40 p.

Ruperez, P., 2002. Mineral content of edible marine seaweeds. Food Chem., 79: 23-36.

(Manuscript received 6 December 2020) 